\title{
CARBON STORAGE IN AN INTACT REPUBLIC OF CONGO'S FOREST
}

\author{
EKoungoulou, R..$^{1,2^{*}}$ - MikouendanANDi, M. R. B. E. ${ }^{3}-$ LiU, X. D. ${ }^{2}$ \\ ${ }^{1}$ Ecole Nationale Supérieure d'Agronomie et de Foresterie, Université Marien Ngouabi, BP 69 \\ Brazzaville, Congo \\ ${ }^{2}$ Beijing Key Laboratory of Forest Resources and Ecosystem Process, College of Forestry, \\ Beijing Forestry University, 100083 Beijing, China \\ ${ }^{3}$ Department of Forest Economics and Management, School of Economics and Management, \\ Beijing Forestry University, 100083 Beijing, China \\ ${ }^{*}$ Corresponding author \\ e-mail: romeoekous@gmail.com; phone: +242-064-640-101
}

(Received 20 $0^{\text {th }}$ Jun 2020; accepted $6^{\text {th }}$ Oct 2020)

\begin{abstract}
Tropical forests are considered major carbon sinks and can help to militate with effectiveness against climate change. The study aimed to assess above-and below-ground biomass and tree carbon storage in Ngoyili tropical forest, and its involvement in sustainable management. The study site is located at Ngoyili forest, in Lesio-louna protected area, in south-eastern Republic of Congo. Trees inventory were performed with circular plots, each $1256 \mathrm{~m}^{2}$, i.e. $40 \mathrm{~m}$ of plot diameter. In five studied plots, trees with $\mathrm{DBH} \geq 10 \mathrm{~cm}$ at $1.3 \mathrm{~m}$ above the ground have been measured and identified. The analyses were conducted using allometric models method. 115 trees recorded were divided into 32 species and 15 families. The results showed that in Ngoyili, the mean storage biomass has been built up for aboveground biomass $\left(273.1\right.$ t.ha $\left.^{-1}\right)$, as well as for belowground biomass $\left(64.1\right.$ tha $\left.^{-1}\right)$, with a significant difference between forest plots $(P<0.001)$. It was obvious that aboveground biomass in plot $3\left(363.8 \mathrm{t} . ~ h a^{-1}\right)$ was higher than those of plot 1, plot 2, plot 4 and plot 5 . Ngoyili forest faces an uncertain future under climate change but can continue to store large amounts of carbon in a warmer world, if countries limit greenhouse gas emissions.
\end{abstract}

Keywords: aboveground biomass, allometric models, belowground biomass, ecosystem, Ngoyili

\section{Introduction}

In recent years, the estimation of forest carbon stocks has gained prominence due to the role of forests in the mitigation of global climate change through carbon storage in biomass (Lewis et al., 2013; Goussanou et al., 2016; Mensah et al., 2017). In line with this, successful implementation of climate change mitigation policies requires accurate estimation and mapping of terrestrial biomass carbon stock. But, the accuracy of estimation depends on the availability of reliable allometric equations as there is a high degree of uncertainty with commonly used pantropic allometric equations (Chave et al., 2014; Ekoungoulou et al., 2014c; Fayolle et al., 2016).

Protecting intact forests is essential to ensuring carbon storage and many other ecosystem services (Pan et al., 2011; Ekoungoulou et al., 2014a). Thus, conserving existing intact forests in combination with restoring and managing sustainably degraded forests is almost certain to be a key action to help meet the Paris accord targets. The idea of financially incentivizing local and national initiatives to spare forest land and favor reforestation has thus received further attention, as evidenced by the united nations' reducing emissions from deforestation, forest degradation, and forest conservation, 
sustainable management of forest, and enhancement of forest carbon stocks (REDD+) program (Chave et al., 2019).

Protected areas in Central Africa are generally managed for biodiversity and recreation with consideration given to the preservation of other services like water or carbon storage (Ekoungoulou et al., 2014b). Their mandate for biodiversity conservation is unquestioned, although not always implemented in a very efficient way and of the 314 protected areas recorded in Central Africa, only 10 sites benefit from a management plan formally approved by the authorities and several important sites (i.e., Garamba and Virunga national parks) are under extreme pressures by armed factions and/or afflux of people displaced by war (Nasi et al., 2012).

There is high degree of uncertainty with commonly used pantropical equation (Ekoungoulou et al., 2018b) to estimate forest biomass carbon stocks (Chave et al., 2014) because, the predictive power of these equations differs among sites; for some regions, the relative error could be low, while for others, it could be high (Chave et al., 2005). For example, in Colombia forest, the type II models of Chave et al. (2005) over estimate aboveground biomass by $54.7 \pm 135.7 \%$ (Alvarez et al., 2012) whereas in Cameroon forest Chave et al. (2005), estimates total aboveground biomass across different sites with an average error of 20.3\% (Djomo et al., 2010). The study of Litton (2008) also showed that the existing generalized allometry underestimate biomass across all size by a mean of $43 \%$ compared to site and species-specific models.

Due to absence of species-specific or mixed-species allometric equations, Africa's forest biomass and carbon stocks has been widely estimated by using pantropical equations (Djomo et al., 2010; Henry et al., 2011; Ekoungoulou, 2014; Ploton et al., 2016). However, tree allometry depends on environmental and genetic factors that vary from region to region (Feldpausch et al., 2012; Vieilledent et al., 2012). Consequently, these equations are unlikely to yield accurate tree biomass estimates at other sites (Vieilledent et al., 2012; Chave et al., 2014). A large number of regression equations have been already published, and the selecting of a limited subset of these, is specifically based on their mathematical simplicity and their applied relevance (Chave et al., 2014; Ekoungoulou, 2018; Sullivan et al., 2020). Typical estimation of aboveground biomass (AGB) in lowland rainforest values vary between 150-700 Mg.ha-1 using the calculation based on the model developed by Chave et al. (2014) which is now a standard model (Eqs. 1 and 2) for tropical forests (Ekoungoulou et al., 2018b; Sullivan et al., 2020). According to the report of recent studies (Henry et al., 2011; Chave et al., 2014; Ngomanda et al., 2014; Fayolle et al., 2016), in Republic of Congo none referential allometric equation existed for the forests of the country. This shows how researchers have been given little attention on the efforts to improve forest biomass and carbon estimation.

This research focused on above-and below-ground biomass assessment, and their carbon stock. The aim of this study was to estimate the trees biomass (aboveground biomass + belowground biomass) and carbon stock in Ngoyili forest ecosystem (Southern Republic of Congo). The results of this study will be useful by the Republic of Congo's Forest Economics Ministry.

\section{Materials and Methods}

\section{Study area}

The study site is located in South-eastern Republic of Congo (S3 ${ }^{\circ} 15.95^{\prime}$; E15 $27.15^{\prime}$ ), in the Pool Administrative Department, close to Lefini wildlife reserve and Kinkala city, 
around $160 \mathrm{~km}$ northern of Brazzaville, in Republic of Congo (Fig. 1). Ngoyili forest ecosystem (study area) is a part of Lesio-louna protected area located in Teke plateau (Fig. 1), close to Imvouba village, and managed by the Lesio-louna project (PLL). However, Teke plateau is a vast area of wooded and non-wooded grasslands interspersed with galleries forests and small dry forest patches, extending from south-east Republic of Gabon through central Republic of Congo and southern Democratic Republic of Congo to northern Republic of Angola. The Lesio-louna reserve lies within central plateau region of Congo. Including the adjacent southern portion of the Lefini wildlife reserve, it reaches an area of approximately $1,748 \mathrm{~km}^{2}$.
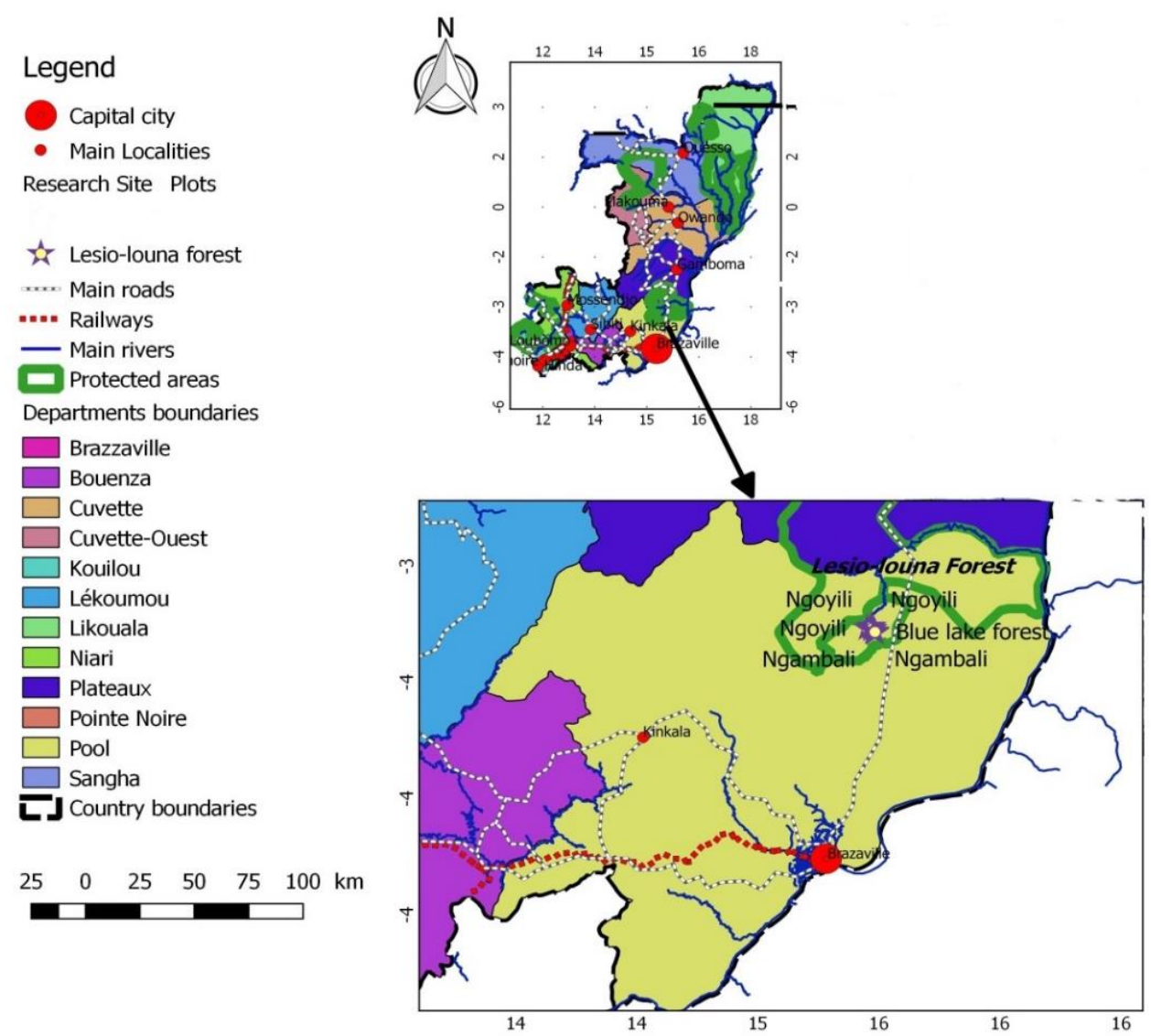

Figure 1. Study area location

\section{Climate}

Climate of Lesio-louna Sanctuary is clearly the same as Teke plateau, Guineo equatorial type, as sub-humid climate Bas Congo. The dry season lasts 3-4 months (June, July, August, September), the short dry season (January-February) is relatively little marked by a slowdown of the rains. The highest annual rainfall recorded in March-April and October-November (ANAC, 2013; Ekoungoulou, 2014). The average temperature is comprised between 20 to $27^{\circ} \mathrm{C}$ and atmospheric moisture is still very high (Fig. 2). From a global view, the Lesio-louna and Teke plateau are subject to the influence of two types of climates as mentioned by ANAC (2013): In northern of Teke plateau (Lesio-louna), there are a climate of sub-equatorial characterized by above $1600 \mathrm{~mm} \cdot \mathrm{an}^{-1}$ rainfall, dry season from 1 to 3 months, an average annual temperature of $22{ }^{\circ} \mathrm{C}$ with seasonal 
amplitudes of $35{ }^{\circ} \mathrm{C}$; In southern of Teke plateau (Lesio-louna) it's a climate of low Congolese type, characterized by below $1600 \mathrm{~mm} \cdot \mathrm{an}^{-1}$ rainfall, dry season of 4-5 months an average annual temperature about $25^{\circ} \mathrm{C}$, with seasonal amplitudes $\left(4\right.$ to $\left.6{ }^{\circ} \mathrm{C}\right)$ (Fig. 2). The climate of Lesio-louna is a tropical equatorial climate which is characterized by the absence of large dry seasons and low temperature differences (ANAC, 2013). Every month, there shall be at least $50 \mathrm{~mm}$ of water. There are two rainy seasons (March-May and September- December) and two dry seasons (June- August and January -February).

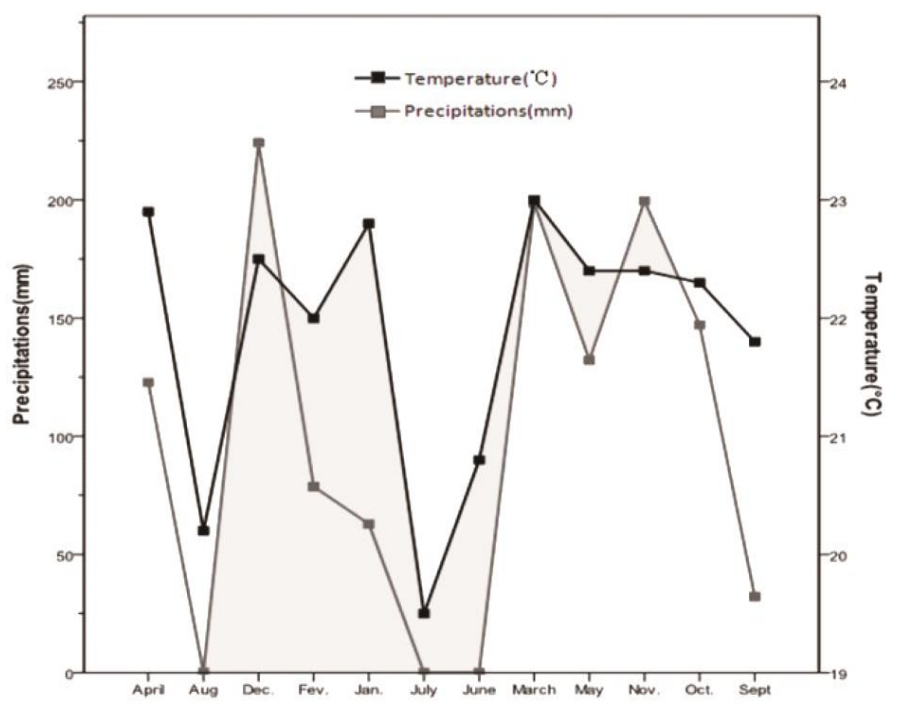

Figure 2. Climograph of the main meteorological station around the study area (mean from 1970 - 2012)

\section{Data collection}

Fieldwork was based on technology using circular plots, each $1256 \mathrm{~m}^{2}$ i.e. $40 \mathrm{~m}$ of diameter. The study had retained 5 circular plots, each separated by roughly $200 \mathrm{~m}$. All data were collected during the period from October to December 2012. A total of 5 inventoried plots were concentered in the site called by Ngoyili gallery forest. Also Ngoyili is an evergreen lowland tropical moist forest. Dendrometry have been performed on plots with a slope $<5^{\circ}$ (almost flat). Measurements have been performed solely on the trees with $\mathrm{DBH} \geq 10 \mathrm{~cm}$ at $1.3 \mathrm{~m}$ heights (Ekoungoulou et al., 2018a), and only these were marked and identified with a nail and polyvinyl chloride plastic label. Thus, equipment such as compass, forestry tape meter, double decameter, GPS has been used during data collection period (Ekoungoulou et al., 2018c). From the circular plot center to the first circle (small circle), the radius was 0-6 m i.e. $12 \mathrm{~m}$ of diameter and tree inventory 10-29.9 cm DBH (only trees with $\mathrm{DBH} \geq 10 \mathrm{~cm}$ were measured). From the plot center to the second circle (medium circle), the radius was $0-14 \mathrm{~m}$ i.e. $28 \mathrm{~m}$ of diameter, with tree inventory $30-60 \mathrm{~cm} \mathrm{DBH}$. From plot center to the third circle (large circle), the radius was 0-20 m i.e. $40 \mathrm{~m}$ of diameter with tree inventory $>60 \mathrm{~cm} \mathrm{DBH}$. Data collected from each plot was then recorded (Ekoungoulou et al., 2017). Field measurements have been conducted according to AfriTRON (www.afritron.org) and forest plots (www.forestplots.net) protocols. 


\section{Data analysis}

\section{Above-and below-ground biomass}

Once measurement field is finished (Ekoungoulou and Mikouendanandi, 2020), the data has been digitized in spreadsheets according to standard procedures outlined in the data organization section (Lopez-Gonzalez et al., 2011). The general checklist of species composing the flora procession has been established (Ekoungoulou et al., 2018a) after digital processing of five sample plots, on the basis of The African plants database (v.3.4.0) of Conservatory and Botanical Garden of Geneva, Switzerland and South African National Biodiversity Institute, Pretoria (Accessed 17 September 2019 at http://www.ville-ge.ch/musinfo/bd/cjb/africa/recherche.php), and The Xycol database (The list of scientific and vernacular woods names: accessed 17 September 2019 at http://www.xycol.net/inde x.php?categorie=0\&sess_langue=430).

Aboveground biomass $(\mathrm{ABG})$ was quantified using generic allometric equations. The allometric equation proposed by Chave et al. (2014) was used for estimation of aboveground biomass (Eqs. 1 and 2). The mathematical expression of the mentioned allometric model (model 7) is as follows:

$$
\begin{gathered}
A G B_{e s t}=\exp [-1.803-0.976 E+0.976 \ln (\rho)+2.673(D) \\
\left.-0.0299[\ln (D)]^{2}\right]
\end{gathered}
$$

where $E$ is defined as:

$$
E=(0.178 \times T S-0.938 \times C W D-6.61 \times P S) \times 10^{-3}
$$

$E$ is a measure of environmental stress; TS is the temperature seasonality; $\ln$ is the natural logarithm; D is diameter at breast height (in $\mathrm{cm}$ ); $A G B_{\text {est }}$ is the estimate aboveground biomass (in $\mathrm{kg}$ ), and $\rho$ (in ${\mathrm{g} . \mathrm{cm}^{-3}}^{-3}$ ) is the wood specific gravity (Zanne et al., 2009; Carsan et al., 2012). Indeed, $E$ increases with temperature seasonality, which relates to the amount of time a plant is exposed to stressful temperature, and a negative quantity CWD (climatic water deficit) increases in magnitude with increasing annualized water stress. The dependence of $E$ on PS (precipitation seasonality) is less obvious but appears to be mostly driven by monsoon dominated rainfall regime (Chave et al., 2014). Wood density $(\rho)$ was extracted from global wood density (Zanne et al., 2009) database (http://datadryad.org/handle/10255/dryad.235: Accessed August 20, 2019). Some wood densities have been provided by African Wood Density Database (Accessed August 20, 2019 at http://apps.worldagroforestry.org/treesandmarkets/wood/) according to Carsan et al. (2012).

However, belowground biomass (BGB) quantification has been made using allometric model (Eqs. 3 and 4) proposed by Mokany et al. (2006). The mathematical expression for this allometric model is as follows:

$$
\begin{gathered}
Y=0.205 \times A G B \text { if } A G B \leq 125 \mathrm{~kg} \\
Y=0.235 \times A G B \text { if } A G B>125 \mathrm{~kg}
\end{gathered}
$$

where $Y$ is belowground biomass (BGB, in $\mathrm{Kg}$ ), and AGB is aboveground biomass (in $\mathrm{kg}$ ). The values of the plots per hectare were extrapolated using an expansion factor which 
indicates the area represented by each plot, and then to finally obtain biomass (AGB and BGB) and carbon stock in t.ha ${ }^{-1}$. This standardization was necessary in order to be able to easily interpret the results and also make comparisons with other studies. Expansion factor is 10,000 (in $\mathrm{m}^{2}$ ) divided by plot area (in $\mathrm{m}^{2}$ ). Biomass and carbon stock have been converted in $\mathrm{t}^{\mathrm{ha}^{-1}}$ after calculation from $\mathrm{Kg}$. Moreover, the estimation of carbon stock has been calculated by dividing biomass by two for each plot. Carbon stock is typically derived from live biomass by assuming $50 \%$ of the biomass is made up carbon (Brown, 1997; Cairns et al., 1997; Basuki et al., 2009; Ekoungoulou et al., 2018b).

\section{Statistical analyses}

Statistical analyses were performed using the softwares called by statistical program from social sciences (SPSS) version 18.0 and SigmaPlot version 10.0. Study area's location map has been performed using the ArcGIS v.9.3 software. Data were analyzed using one-way ANOVA (Ekoungoulou and Mikouendanandi, 2020). Separations were performed by Duncan's multiple range tests. Differences at $P<0.05$ were considered to be significant. The means and sample variance were equal in all five studied plots during the research period according to analysis performed with statistical program from social sciences.

\section{Results and Discussion}

The investigation revealed a total number of 115 trees with $\mathrm{DBH} \geq 10 \mathrm{~cm}$ in the study area have been recorded. These grouped trees were belonged to 15 botanical families and 32 species. A total of 115 trees were divided into 5 plots (Table 1). Floristic richness shows the total number of species, present in Ngoyili forest. The most represented species in study site with height relative diversity index were Eriocoelum macrocarpum Gilg ex Radlk ( $n=21$, recorded in all 5 studied plots), followed by Xylopia rubescens Oliv. var. rubescens $(n=10$, present in plot 1, plot 4 and plot 5). In this Ngoyili riparian forest, the most number of trees were recorded in plot $3(n=30)$, followed by plot $1(n=24)$, plot 4 $(n=24)$, plot $2(n=20)$, and plot $5(n=17)$. It was obvious that aboveground biomass (AGB) in plot 3 (363.8 t.ha ${ }^{-1}$ ) were higher than those of plot 1, plot 2, plot 4 and plot 5 (Fig. 3 and Table 1). The higher belowground biomass (BGB) has been recorded in plot 3 with 85.5 t.h $^{-1}$ (Fig. 3). However, Fig. 4 b shows that the mean diameter at breast height $(\mathrm{DBH})$ recorded in plot 1 was higher than those of others studied plots; but the mean AGB and BGB of plot 1 was less than those of plot 3 and plot 4 .

Table 1. Distribution of tree biomass in Ngoyili tropical gallery forest and description of the study site

\begin{tabular}{c|c|c|c|c|c}
\hline Plot & $n$ & AGB & BGB & DBH & Area State \\
\hline Plot1 & 24 & 273.9 & 64.3 & 31.7 & Swampy \\
Plot2 & 20 & 236.6 & 55.6 & 25.9 & Swampy \\
Plot3 & 30 & 363.8 & 85.5 & 29.8 & Swampy \\
Plot4 & 24 & 293.6 & 69 & 26.9 & Swampy \\
Plot5 & 17 & 197.5 & 46.4 & 28.2 & AUE \\
\hline
\end{tabular}

DBH: average diameter at breast height of trees (in $\mathrm{cm}$ ), AGB: Aboveground biomass (t.ha ${ }^{-1}$ ), BGB: Belowground biomass $\left(\right.$ t.ha $\left.{ }^{-1}\right)$, AUE: An undisturbed ecosystem with a terra firme area, n: number of trees 


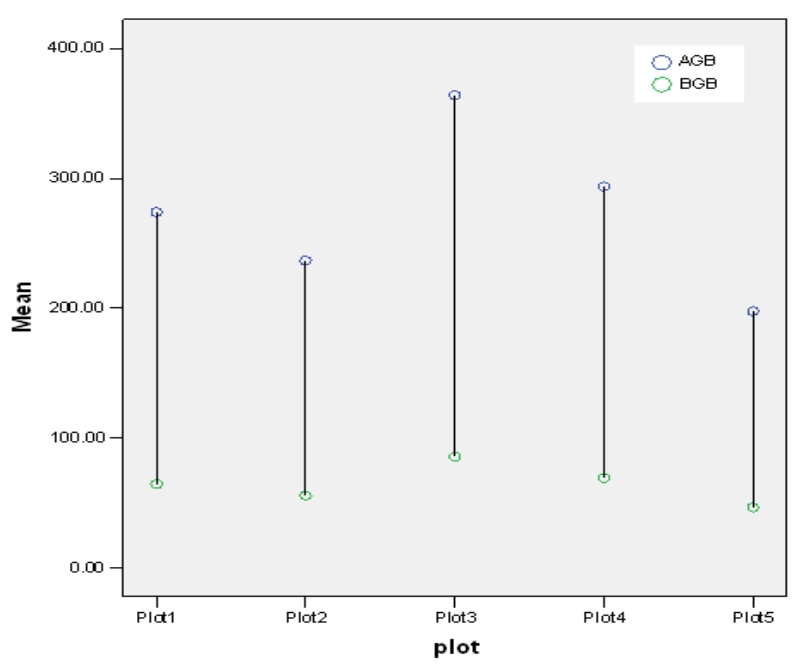

Figure 3. Relationship between mean aboveground biomass $\left(A G B\right.$, in t.ha $\left.a^{-1}\right)$ and mean belowground biomass $\left(B G B\right.$, in t.ha $\left.a^{-1}\right)$ by plot in Ngoyili forest using allometric models with the point style graph

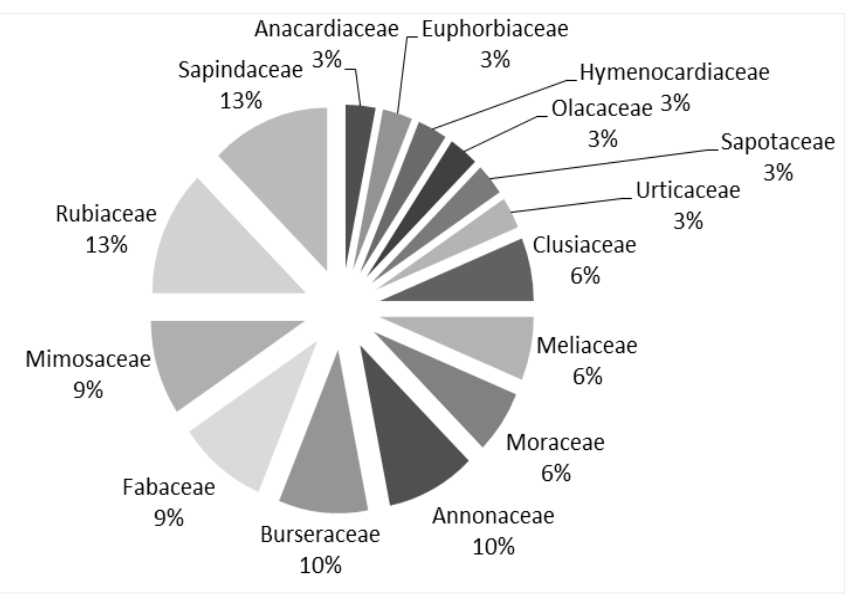

(a)

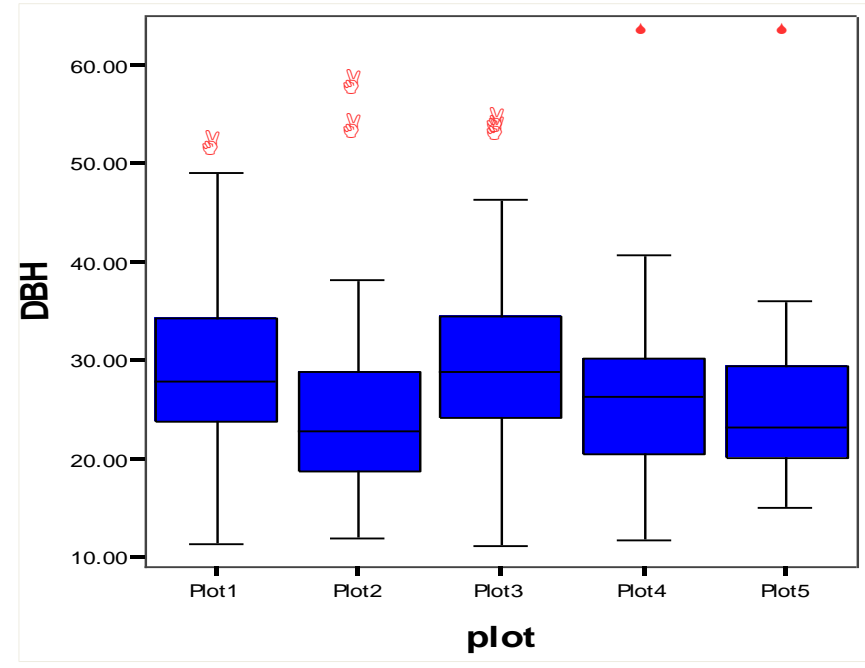

(b)

Figure 4. Phytodiversity overview including trees diameters distribution of Ngoyili forest ecosystem. (a) Relative frequency of specific spectra families recorded in study area. (b) Mean trunk diameters distribution of trees by plot in study site (in $\mathrm{cm}$ ) 
Table 1 shows that plot 1 (273.9 t.ha $\left.{ }^{-1}\right)$ has a lower AGB than plot 3 (363.8 t.ha $\left.{ }^{-1}\right)$, while the DBH of plot $1(31.7 \mathrm{~cm})$ is higher than plot $3(29.8 \mathrm{~cm})$. BGB of plot 1 $\left(64.3\right.$ t.ha $\left.^{-1}\right)$ is low compared to plot $3\left(85.5\right.$ t.ha $\left.^{-1}\right)$, while the DBH of plot $3(29.8 \mathrm{~cm})$ is lower than that of plot $1(31.7 \mathrm{~cm})$. Since the area state is the same, both for plot 1 and plot 3 , so this difference in biomass could be due to the nature and composition of plots' soil. The results showed that in Ngoyili mixed evergreen forest ecosystem, the mean biomass has been built up for AGB (273.1 t.ha-1) as well as for BGB $\left(64.1 \mathrm{t}^{-1} \mathrm{ha}^{-1}\right)$, with a significant difference between forest plots $(P<0.001)$. One-way ANOVA applied on five plots data of Ngoyili statistically revealed significant difference regarding the test for equal means $(P<0.001$, confidence interval at 95\%). Levene's test for homogeneity of variance for means shows a significant difference $(P=0.012)$.

Also, Table 2 shows that the trees in plot 3 are neither from Fabaceae, nor from Mimosaceae. Leguminosea plants have the ability to capture nitrogen from the atmosphere. Fabaceae and Mimosaceae are taxonomically the Leguminosea, and have the capacity to enrich the soil with atmospheric nitrogen through the symbiotic phenomenon between the rhizobium bacteria and the nodules of the roots from Leguminosea plants (PROTA, 2008). In this ecosystem, the most represented botanical families are those of Sapindaceae (4 tree species), followed by Rubiaceae ( 4 tree species), then Mimosaceae (3 tree species), Burseraceae (3 tree species), Annonaceae (3 tree species) and Fabaceae with 3 tree species (Fig. 4a). In Sapotaceae (3\%), Euphorbiaceae (3\%), Hymenocardiaceae (3\%) a very low proportion of relative frequency of botanical families were founded (Fig. 4a). Contrariwise, the weakliest represented botanical families each have one species. These are the following families: Urticaceae, Sapotaceae, Olacaceae, Hymenocardiaceae, Euphorbiaceae and Anacardiaceae (Fig. 4a).

Relatively few studies to date have quantified the measurement error or model uncertainty associated with the estimates of forest biomass. In one of the comprehensive studies, Chave et al. (2004) assessed the effects of measurement error (stem diameter), model uncertainty associated with height-diameter relationships, and sampling uncertainty on estimates of tropical carbon stock in Panama. They reported that the uncertainty (standard deviation) in the aboveground biomass for individual trees averaged $47 \%$ of the estimate, with $31 \%$ arising from uncertainty in the allometric model and $16 \%$ from measurement error. At the stand level, however, the effect of measurement error was reduced to less than $1 \%$, and the total uncertainty reduced to $10 \%$ due to allometric uncertainty and $10 \%$ due to sampling uncertainty.

About the long-term thermal sensitivity of Earth's tropical forests, Sullivan et al. (2020) indicates a heat threshold of $32{ }^{\circ} \mathrm{C}$ in daytime temperature. Above this point tropical forest carbon declines more quickly with higher temperatures, regardless of which species are present. Sullivan et al. (2020) conclude that tropical forests have longterm capacity to adapt to some climate change, in part because of their high biodiversity, as tree species better able to tolerate new climatic conditions grow well and replace less well-adapted species, over the long-term.

In another study, Djomo et al. (2010) propagated uncertainty in carbon stock estimates in tropical forest in Cameroon using the statistical propagation techniques described in Chave et al. (2005), and reported that uncertainty in allometric equations contributed $30 \%$ of the total uncertainty in carbon stock estimates. These estimates may have overestimated the uncertainty due to allometric models (Yanai et al., 2010). Another limitation of these studies is that they have focused on tropical forests. Previous studies 
have tended to focus on uncertainty in carbon stock estimates (Ekoungoulou et al., 2015), rather than uncertainty in carbon change over time.

Table 2. Distribution of species by family recorded in Ngoyili forest

\begin{tabular}{|c|c|c|c|c|c|}
\hline Species & Family & $n$ & $\rho$ & DBH & Plot \\
\hline Allophylus africanus P. Beauv. & Sapindaceae & 2 & 0.450 & $12.6-13.7$ & P3 \\
\hline Berlinia bracteosa Benth. & Annonaceae & 4 & 0.603 & $18.8-34$ & P3, P5 \\
\hline $\begin{array}{c}\text { Colletoecema dewevrei (De Wild.) } \\
\text { E.M.A. Petit }\end{array}$ & Rubiaceae & 1 & 0.650 & 23.3 & $\mathrm{P} 2$ \\
\hline Colletoecema spp. & Rubiaceae & 1 & 0.650 & 57 & $\mathrm{P} 2$ \\
\hline Dacryodes buettneri (Engl.) H.J.Lam & Burseraceae & 6 & 0.513 & $11.4-30.8$ & $\mathrm{P} 1, \mathrm{P} 2, \mathrm{P} 4$ \\
\hline Dacryodes letestui (Pellegr.) H. J. Lam & Burseraceae & 3 & 0.548 & $21.1-25.6$ & $\mathrm{P} 1, \mathrm{P} 2$ \\
\hline Dacryodes spp. & Burseraceae & 1 & 0.561 & 23.3 & $\mathrm{P} 2$ \\
\hline $\begin{array}{c}\text { Entandrophragma cylindricum (Sprague) } \\
\text { Sprague }\end{array}$ & Meliaceae & 2 & 0.572 & $25.6-38.4$ & P3 \\
\hline $\begin{array}{c}\text { Entandrophragma utile (Dawe \& } \\
\text { Sprague) Sprague }\end{array}$ & Meliaceae & 1 & 0.537 & 24.5 & P3 \\
\hline Eriocoelum macrocarpum Gilg ex Radlk. & Sapindaceae & 21 & 0.523 & $15.8-53.1$ & $\begin{array}{l}\text { P1, P2, P3, } \\
\text { P4, P5 }\end{array}$ \\
\hline Eriocoelum spp. & Sapindaceae & 3 & 0.523 & $22.8-31.9$ & P3, P4 \\
\hline Ficus deltoidea Jack & Moraceae & 2 & 0.650 & $29-38.3$ & P3 \\
\hline Ficus spp. & Moraceae & 1 & 0.410 & $29-33.4$ & P3 \\
\hline Hymenocardia ulmoides Oliv. & Hymenocardiaceae & 3 & 0.702 & $22.9-33.8$ & P5 \\
\hline Millettia laurentii De Wild. & Fabaceae & 3 & 0.761 & $11.9-52.5$ & $\mathrm{P} 2$ \\
\hline Millettia pinnata $\mathrm{L}$. & Fabaceae & 2 & 0.650 & $21.2-33.8$ & P4 \\
\hline Mitragyna spp. & Rubiaceae & 2 & 0.528 & $34.6-46.3$ & P3 \\
\hline Mitragyna stipulosa (DC.) Kuntze & Rubiaceae & 9 & 0.575 & $11.2-63$ & $\begin{array}{l}\mathrm{P} 1, \mathrm{P} 3, \mathrm{P} 4, \\
\text { P5 }\end{array}$ \\
\hline Musanga cecropioides $\mathrm{R}$. Br. & Urticaceae & 2 & 0.243 & $20.1-32.4$ & P5 \\
\hline Omphalocarpum elatum Miers & Sapotaceae & 1 & 0.550 & 29.8 & $\mathrm{P} 2$ \\
\hline Ongokea gore (Hua) Pierre & Olacaceae & 3 & 0.749 & $11.4-40.7$ & $\mathrm{P} 1$ \\
\hline $\begin{array}{c}\text { Pancovia laurentii (De Wild.) Gilg ex De } \\
\text { Wild. }\end{array}$ & Sapindaceae & 1 & 0.650 & 15.6 & $\mathrm{P} 2$ \\
\hline $\begin{array}{c}\text { Pentaclethra eetveldeana De Wild. \& T. } \\
\text { Durand }\end{array}$ & Mimosaceae & 8 & 0.663 & $16.4-33.2$ & $\mathrm{P} 2, \mathrm{P} 5$ \\
\hline Pentaclethra macrophylla Benth. & Fabaceae & 1 & 0.841 & 50.9 & $\mathrm{P} 1$ \\
\hline $\begin{array}{c}\text { Piptadeniastrum africanum (Hook. f.) } \\
\text { Brenan }\end{array}$ & Mimosaceae & 7 & 0.605 & $18-40.8$ & $\mathrm{P} 1, \mathrm{P} 4, \mathrm{P} 5$ \\
\hline Piptadeniastrum spp. & Mimosaceae & 1 & 0.605 & 15 & P5 \\
\hline $\begin{array}{c}\text { Sorindeia juglandifolia (A.Rich.) Planch. } \\
\text { ex Oliv. }\end{array}$ & Anacardiaceae & 4 & 0.650 & $14.3-31.5$ & $\mathrm{P} 1, \mathrm{P} 3, \mathrm{P} 4$ \\
\hline Symphonia globulifera L.f. & Clusiaceae & 5 & 0.600 & $14-31.5$ & P3, P4 \\
\hline Symphonia spp. & Clusiaceae & 1 & 0.600 & 35.7 & P3 \\
\hline Uapaca heudelotii Baill. & Euphorbiaceae & 3 & 0.614 & $24.6-52.3$ & P3 \\
\hline Xylopia aethiopica (Dunal) A. Rich. & Annonaceae & 1 & 0.442 & 38.3 & P2 \\
\hline Xylopia rubescens Oliv. var. rubescens & Annonaceae & 10 & 0.615 & $11.7-49.1$ & $\mathrm{P} 1, \mathrm{P} 4, \mathrm{P} 5$ \\
\hline
\end{tabular}

DBH is ranged diameter at breast height of trees (in $\mathrm{cm}$ ); $n$ is number of tree; $\rho$ is mean of wood density (wood specific gravity, in $\mathrm{g} . \mathrm{cm}^{-3}$ ) values retrieved from the global wood density database at http://datadryad.org/handle/10255/dryad.235: Accessed August 20, 2019, and African Wood Density Database at http://apps.worldagroforestry.org/treesandmarkets/wood/ : Accessed August 20, 2019; P is plot which tree species has been founded in each area. Trees taxonomy was homogenized according to the African plants database (version 3.4.0) from Conservatory and Botanical Garden of Geneva, Switzerland and South African National Biodiversity Institute, Pretoria (Accessed 17 September 2019 at http://www.ville-ge.ch/musinfo/bd/cjb/africa/recherche.php), and The Xycol database (The list of scientific and vernacular woods names: accessed 17 September 2019 at http://www.xycol.net/inde x.php?categorie $=0 \&$ sess_langue $=430$ ) 
Regarding field methods for sampling tree height for tropical forest biomass estimation, Sullivan et al. (2018) founded that allometries constructed with just 20 locally measured values could often predict tree height with lower error than regional or climatebased allometries (mean reduction in prediction error is $0.46 \mathrm{~m}$ ). The prediction performance of locally derived allometries improved with sample size, but with diminishing returns in performance gains when more than forty trees were sampled. Estimate of stand-level biomass produced using local allometries to estimate tree height show no over- or under- estimate bias when compared with biomass estimates using field measurement, and found that sampling strategies that included measuring the heights of the ten largest diameter in a plot outperformed (in terms of resulting in local heightdiameter models with low height prediction error) entirely random of diameter size-class stratified approaches.

With regard to our present study, difference in biomass storage could certainly be the type of tree species, nature of tree, composition and nature of plots' soil. There are many Fabaceae trees in this Ngoyili mixed evergreen forest ecosystem, which is characterized by growth and a spectacular development as reported by Ekoungoulou et al. (2014c). Therefore, the roots of Fabaceae's trees have swellings called nodules that contain nitrogen-fixing bacteria (PROTA, 2008; Fayolle et al., 2013; Ekoungoulou, 2014). These key factors mentioned, resulted in heterogeneity of biomass play an important role about carbon storage, carbon gains, and carbon residence time and carbon balance. Environmental variations have also an impact on carbon storage.

However, a possible alternative to use a model integrating tree height into biomass estimation based on diameter measurements in forest inventory would be better for the future studies. Carbon change is arguably the more important of two metrics as it is the basis for United Nations Framework Convention on Climate Change (UNFCCC) reporting, including programmes such as REDD+ which is designed to incentivize management of forests for increased carbon sequestration (Holdaway et al., 2014). Furthermore, the variation of carbon stocks in this protected area could be due to the fact that wet soil of this riparian forest is a peat ecosystem in several places. Peatlands play a key role in storing carbon in the soil, and also supplying trees with nutrients. The present study provided new data appropriate for next carbon cartography as part to monitor forest carbon in Republic of Congo. Based on the uncertainty of these present equations, we suggested that the uncertainty of future models may be probably less important with the carbon equation when calculating carbon stocks with double time periods.

\section{Conclusion}

Tropical forests had a key role in mitigation of greenhouse gases in atmosphere. These forests are considered as major carbon sinks and can help to militate against climate change. The validity of pantropical equations, however, remains to be tested in particular environmental conditions, i.e. swamps or temporarily flooded forest, which may constrain the allometric relationship between height and diameter. Including height parameter in allometric equations which reflects growing conditions could improve their accuracy and applicability. This study allowed us to understand that Ngoyili riparian mixed tropical forest's plot 3 (363.8 t.ha ${ }^{-1}$ and 85.5 t.ha ${ }^{-1}$ for aboveground biomass and belowground biomass respectively) has recorded a higher carbon stock compared to others plots in the same site of protected area. The results of this work revealed that in Ngoyili forest tree biomass and carbon stock varied by tree species and also by sampled plot. This evergreen 
intact tropical forest can participate effectively to mitigate the global climate change by photosynthesis phenomenon. The findings of this study will be used by REDD+ Congo project managed by CN-REDD+, under the supervision of Republic of Congo's Ministry of Forest Economics, and then to help country to receive carbon credit through voluntary carbon market. This study can serve as a support or a milestone for researchers working in the same field, in order to address the influence of climate and soil on the heterogeneity of carbon quantification in each forest and each carbon reservoir.

Acknowledgements. The authors would like to thank Chinese government under the China Scholarship Council (www.csc.edu.cn) and Beijing Forestry University (www.bjfu.edu.cn) for supporting this work. We greatly acknowledge Superior National School for Agronomy and Forestry (Ecole Nationale Supérieure d'Agronomie et de Foresterie - ENSAF) from Marien Ngouabi University (Université Marien Ngouabi www.umng.cg) for its contribution. The National Key Research and Development Project of China (2017YFD0600106) also supported this study. Two anonymous referees have provided substantial contribution and the authors address to them their heartfelt thanks.

Conflicts of Interests. The authors have declared that no competing interests exist. The founding sponsors had no role in the design of the study; in the collection, analyses, or interpretation of data; in the writing of the manuscript, and in the decision to publish the results.

\section{REFERENCES}

[1] Alvarez, E., Duque, A., Saldarriaga, J., Cabrera, K., De las Salas, G., Del Valle, I. (2012): Tree above-ground biomass allometries for carbon stocks estimation in the natural forests of Colombia. - Forest Ecology and Management 267: 297-308.

[2] ANAC, National Agency of Congo's Civil Aviation (2013): Annual Report on Congolese Meteorological National Situation. - National Agency of Congo's Civil Aviation, Brazzaville, Congo (in French).

[3] Basuki, T. M., van Laake, P. E., Skidmore, A. K., Hussin, Y. A. (2009): Allometric equations for estimating the above-ground biomass in tropical lowland Dipterocarp forests. - Forest Ecology and Management 257: 1684-1694.

[4] Brown, S. (1997): Estimating Biomass and Biomass Change of Tropical Forests: A Primer. FAO Forestry Paper 134. - Food and Agriculture Organization of the United Nations, Rome, Italy.

[5] Cairns, A. M., Brown, S., Helmer, H. E., Baumgardner, A. G. (1997): Root biomass allocation in the world's upland forests. - Oecologia 111: 1-11.

[6] Carsan, S., Orwa, C., Harwood, C., Kindt, R., Stroebel, A., Neufeldt, H., Jamnadass, R. (2012): African Wood Density Database. - World Agroforestry Centre, Nairobi, Kenya, http://apps.worldagroforestry.org/treesandmarkets/wood/ [Accessed 08.20.2019].

[7] Chave, J., Condit, R., Aguilar, S., Hernandez, A., Lao, S., Perez, R. (2004): Error propagation and scaling for tropical forest biomass estimates. - Philosophical Transactions of the Royal Society: Biological Sciences 359(1443): 409-420.

[8] Chave, J., Andalo, C., Brown, S., Cairns, M. A., Chambers, J. Q., Eamus, D. (2005): Tree allometry and improved estimation of carbon stocks and balance in tropical forests. Oecologia 145(1): 87-99.

[9] Chave, J., Rejou-Mechain, M., Burquez, A., Chidumayo, E., Colgan, M. S., Delitti, W. B. C. (2014): Improved allometric models to estimate the aboveground biomass of tropical trees. - Global Change Biology 20(10): 3177-3190.

[10] Chave, J., Davies, J. S., Phillips, L. O., Lewis, L. S., Sist, P., Schepaschenko, D. (2019): Ground Data Are Essential for Biomass Remote Sensing Missions. - Surveys in Geophysics 40: 863-880. 
[11] Djomo, N. A., Ibrahima, A., Saborowski, J., Gravenhorst, G. (2010): Allometric equations for biomass estimations in Cameroon and pan moist tropical equations including biomass data from Africa. - Forest Ecology and Management 260: 1873-1885.

[12] Ekoungoulou, R. (2014): Carbon Stocks Evaluation in Tropical Forest, Congo. Carbon Stocks in Forest Ecosystems. - Lambert Academic Publishing, Saarbrucken, Germany.

[13] Ekoungoulou, R., Liu, X. D., Ifo, S. A., Loumeto, J. J., Folega, F. (2014a): Carbon stock estimation in secondary forest and gallery forest of Congo using allometric equations. International Journal of Scientific \& Technology Research 3(3): 465-474.

[14] Ekoungoulou, R., Liu, X. D., Loumeto, J. J., Ifo, S. A. (2014b): Tree Above-And BelowGround Biomass Allometries for Carbon Stocks Estimation in Secondary Forest of Congo. - Journal of Environmental Science, Toxicology and Food Technology 8(4): 09-20.

[15] Ekoungoulou, R., Liu, X. D., Loumeto, J. J., Ifo, S. A., Bocko, Y. E., Koula, F. E., Niu, S. (2014c): Tree allometry in tropical forest of Congo for carbon stocks estimation in aboveground biomass. - Open Journal of Forestry 4(5): 481-491.

[16] Ekoungoulou, R., Niu, S. K., Loumeto, J. J., Ifo, S. A., Bocko, Y. E., Liu, X. D. (2015): Evaluating the carbon stock in above-and below-ground biomass in a moist central African forest. - Applied Ecology and Environmental Sciences 3(2): 51-59.

[17] Ekoungoulou, R., Nzala, D., Liu, X. D., Niu, S. K. (2017): Ecological and structural analyses of trees in an evergreen lowland Congo basin forest. - International Journal of Biology 10(1): 31-43.

[18] Ekoungoulou, R. (2018): Managing Tropical Forest Ecosystems. Tropical Trees. - Lambert Academic Publishing, Saarbrucken, Germany.

[19] Ekoungoulou, R., Folega, F., Mukete, B., Ifo, S. A., Loumeto, J. J., Liu, X. D., Niu, S. K. (2018a): Assessing the effectiveness of Protected Areas on Floristic Diversity in Tropical Forests. - Applied Ecology and Environmental Research 16(1): 837-853.

[20] Ekoungoulou, R., Nzala, D., Liu, X. D., Niu, S. K. (2018b): Tree biomass estimation in central African forests using allometric models. - Open Journal of Ecology 8(3): 209-237.

[21] Ekoungoulou, R., Niu, S. K., Folega, F., Nzala, D., Liu, X. D. (2018c): Carbon stocks of coarse woody debris in central African tropical forests. - Sustainability in Environment 3(2): 142-160.

[22] Ekoungoulou, R., Mikouendanandi, E. B. R. M. (2020): Lettuce (Lactuca sativa L.) Production in Republic of Congo Using Hydroponic System. - Open Access Library Journal 7(5): e6339.

[23] Fayolle, A., Doucet, J. L., Gillet, J. F., Bourland, N., Lejeune, P. (2013): Tree allometry in Central Africa: Testing the validity of pantropical multi-species allometric equations for estimating biomass and carbon stocks. - Forest Ecology and Management 305: 29-37.

[24] Fayolle, A., Panzou, G. J. L., Drouet, T., Swaine, M. D., Bauwens, S., Vleminckx, J., Doucet, J. L. (2016): Taller Trees, Denser Stands and Greater Biomass in Semi-Deciduous than in Evergreen Lowland Central African Forests. - Forest Ecology and Management 374: 42-50.

[25] Feldpausch, T. R., Lloyd, J., Lewis, S. L., Brienen, R. J. W., Gloor, M., Monteagudo, M. A. (2012): Tree Height Integrated into Pantropical Biomass Forest Estimates. Biogeosciences 9: 3381-3403.

[26] Goussanou, C. A., Guendehou, S., Assogdadjo, A. E., Kaire, M., Sinsin, B., Cuni-Sanchez, A. (2016): Specific and generic stem biomass and volume models of trees in a West Africa tropical semi-deciduous forest. - Silva Fennica 50(2): 1-22.

[27] Henry, M., Picard, N., Trotta, C., Manlay, R. J., Valentini, R., Bernoux, M., Saint-Andre, L. (2011): Estimating tree biomass of sub-sahara African forests: a review of available allometric equations. - Silva Fennica 45(3): 477-569.

[28] Holdaway, J. R., McNeill, S. J., Mason, N. W. H., Carswell, F. E. (2014): Propagating Uncertainty in Plot-Based Estimates of Forest Carbon Stock and Carbon Stock Change. Ecosystems 17: 627-640. 
[29] Lewis, S. L., Sonke, B., Sunderland, T., Begne, S. K., Lopez-Gonzalez, G., van der Heijden, G. M. F., Zemagho, L. (2013): Above-ground biomass and structure of 260 African tropical forests. - Philosophical Transactions of the Royal Society: Biological Sciences 368: 20120295.

[30] Litton, C. M. (2008): Allometric models for predicting aboveground biomass in two widespread wood plants in Hawaii. - Biotropica 40(3): 313-320.

[31] Lopez-Gonzalez, G., Lewis, S. L., Burkitt, M., Phillips, O. L. (2011): ForestPlots.net: a web application and research tool to manage and analyse tropical forest plot data. - Journal of Vegetation Science 22: 610-613.

[32] Mensah, S., Veldtman, R., Seifert, T. (2017): Allometric Models for Height and Aboveground Biomass of Dominant Tree Species in South African Mistbelt Forests. Southern Forests: A Journal of Forest Science 79: 19-30.

[33] Mokany, K., Raison, R. J., Prokushkin, A. S. (2006): Critical analysis of root: shoot ratios in terrestrial biomes. - Global Change Biology 12(1): 84-96.

[34] Nasi, R., Billand, A., Vanvliet, N. (2012): Managing for timber and biodiversity in the Congo Basin. - Forest Ecology and Management 268: 103-111.

[35] Ngomanda, A., Obiang, N. L. E., Lebamba, J., Mavouroulou, Q. M., Mankou, G. S., Picard, N. (2014): Site-Specific versus Pantropical Allometric Equations: Which Option to Estimate the Biomass of A Moist Central African Forest? - Forest Ecology and Management 312: 1-9.

[36] Pan, Y., Birdsey, R. A., Fang, J., Houghton, R., Kauppi, P. E., Kurz, W. A. (2011): A Large and Persistent Carbon Sink in the World's Forests. - Science 333(6045): 988-993.

[37] Ploton, P., Barbier, N., Takoudjou-Momo, T. S., Rejou-Mechain, M., Bosela, B. F., Chuyong, G. (2016): Closing a Gap in Tropical Forest Biomass Estimation: Taking Crown Mass Variation into Account in Pantropical Allometries. - Biogeosciences 13: 1571-1585.

[38] PROTA, Plant Resources of Tropical Africa (2008): Lumber 1. Plant Resources of Tropical Africa. - Backhuys Publishers, CTA. Wageningen, Netherlands (in French).

[39] Sullivan, J. P. M., Lewis, L. S., Hubau, W., Qie, L., Baker, R. T., Banin, F. L. (2018): Field methods for sampling tree height for tropical forest biomass estimation. - Methods in Ecology and Evolution 9: 1179-1189.

[40] Sullivan, J. P. M., Lewis, L. S., Affum-Baffoe, K., Castilho, C., Ekoungoulou, R., Phillips, O. L. (2020): Long-term thermal sensitivity of Earth's tropical forests. - Science 368(6493): 869-874.

[41] Vieilledent, G., Vaudry, R., Andriamanohisoa, S. F. D., Rakotonarivo, O. S., Randrianasolo, H. Z., Razafindrabe, H. N. (2012): A Universal Approach to Estimate Biomass and Carbon Stock in Tropical Forests Using Generic Allometric Models. Ecological Applications 22(2): 572-583.

[42] Yanai, D. R., Battles, J. J., Richardson, D. A., Blodgett, A. C., Wood, M. D., Rastetter, B. E. (2010): Estimating uncertainty in ecosystem budget calculations. - Ecosystems 13(2): 239-248.

[43] Zanne, A. E., Lopez-Gonzalez, G., Coomes, D. A., Jansen, S., Lewis, S. L., Miller, R. B., Chave, J. (2009): Data from: Towards a Worldwide Wood Economics Spectrum. - Global Wood Density Database. V2, Dryad Digital Repository, Dataset: https://datadryad.org/stash/dataset/doi:10.5061/dryad.234 [Accessed 08.20.2019]. 